\title{
Factors That Influence an Undergraduate Student to Choose a Career in Aviation, and Enroll in the Aviation Science Program at Parks College of Engineering, Aviation and Technology
}

\author{
Richard Steckel, Damon Lercel, and Hisako Matsuo \\ Saint Louis University
}

\begin{abstract}
A study was conducted in the Aviation Science Department, Parks College of Engineering, Aviation and Technology, Saint Louis University, to determine the factors that influence undergraduate students to choose aviation as a career field and Parks College as their choice for their aviation education. This information was gathered to assist Parks College in determining the most effective measures to recruit and retain undergraduate students and what other measures might be considered to improve a student's educational experience at Parks. A paper survey instrument consisting of eight pertinent demographic questions, 67 Likert scale questions, and five open-ended questions were given to a convenience sample of four aviation science classes: one freshman class, one sophomore class, one junior class, and one senior class. The survey population consisted of undergraduate aviation science and aviation management majors. The results of the survey and conclusions are discussed.
\end{abstract}

\section{INTRODUCTION}

The authors were requested to design, conduct, analyze, and report on a survey as a class project for a graduate sample survey methods class. Since the authors were aviation graduate students, they took advantage of the project and asked the Aviation Science department chair what information from a no cost survey would be of interest him. The chair stated that it would be useful to the department to determine why aviation science undergraduate students chose this particular university for their aviation education, and why these same students chose aviation as a career field. This information could be used by the Aviation Science Department to determine the best use of a limited budget to attract and retain undergraduate aviation science students.

\section{REVIEW OF LITERATURE}

A literature review was conducted to determine what types of other surveys had been conducted in the past that attempted to determine why undergraduate students picked their particular university for an aviation education. Saint Louis University survey results from 1991 (Wendt, 1991) were obtained from the Dean's office for review. Many of the questions from this 1991 survey were similar to the American National Norms 1990 project (Astin, Korn, \& Berz, 1991). A comparison of these two surveys was performed. Many of the questions were demographic in nature, and explored what types of students were enrolling at the university, while some of the questions asked why they had chosen the university. We were unable to obtain the survey instrument to determine all of the questions asked, and many of the survey results reported just the top reasons, rather than ranking or reporting all of the responses. The top 3 reasons in 1991, which were also mirrored in the national survey, for students picking the university, were:

1. Good academic reputation

2. Graduates get good jobs

3. Size of the college 
Top 3 reasons for their choice of aviation as a career were:

1. Work would be challenging

2. Job openings generally available

3. High anticipated earnings

Of the students surveyed, $86 \%$ said that Saint Louis University was their first choice of the universities offering aviation curriculums. A more recent survey by Clark (2004) that surveyed incoming freshmen at 23 collegiate aviation programs reported the top ten factors for choosing a four year post secondary aviation program (Table 1).

Table 1. Clark (2004) Factor Ranking

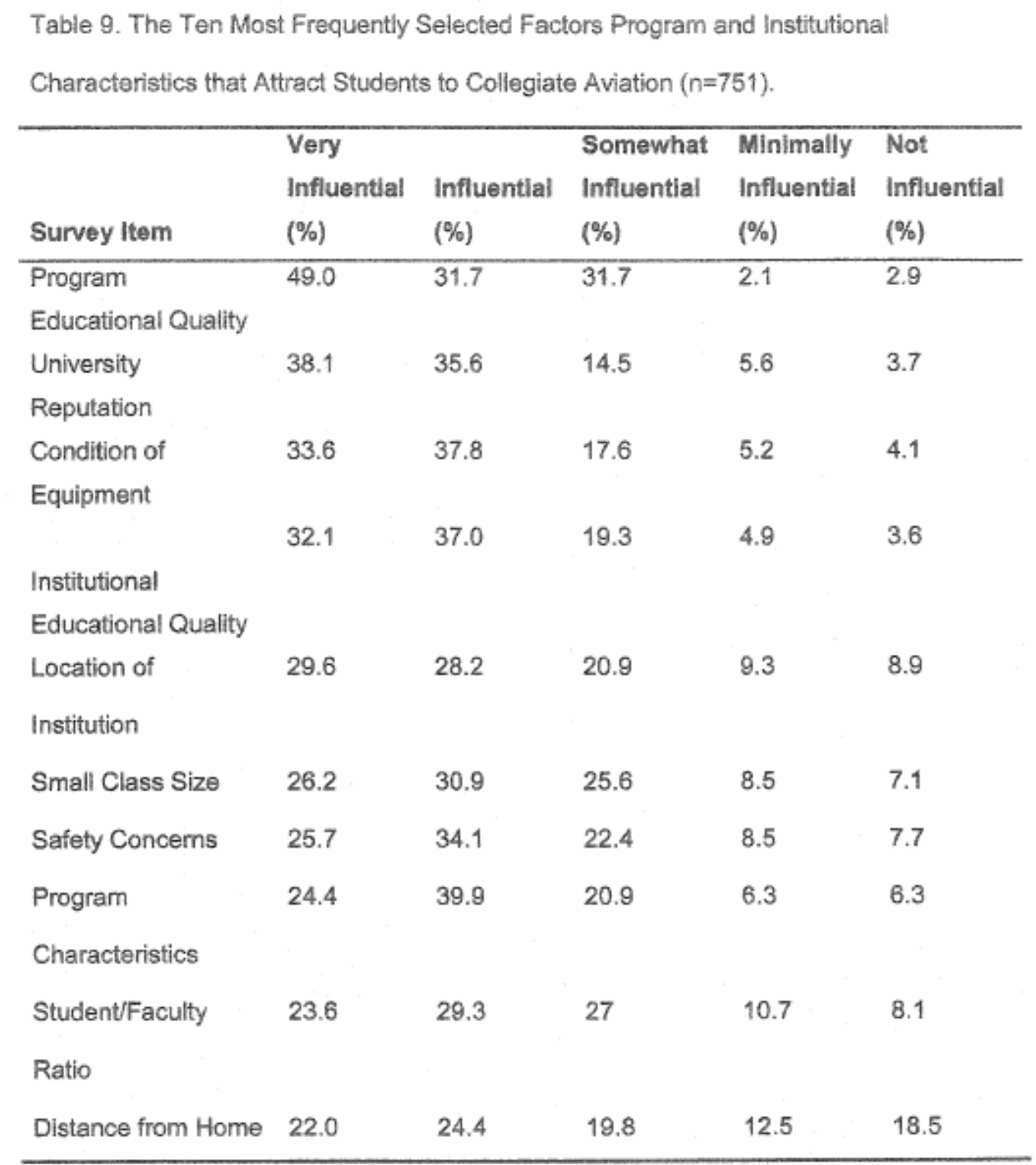

Note. The values may not oqual $100 \%$ due to missing data. 


\section{METHODOLOGY}

The instrument chosen for the survey was a paper survey administered at the beginning of each undergraduate class selected for the survey. The survey (Appendix A) consisted of 37 Likert scale questions asking the student how influential each factor was in choosing Parks college, and 23 Likert scale questions asking both how influential each factor was in choosing aviation as a career and how much the student agreed or disagreed with the statement (1-strongly disagree, 2-disagree, 3-slightly disagree, 4-neutral, 5-slightly agree, 6- agree, 7-strongly agree). There were also five Likert scale questions asking the student's satisfaction with choice of career and choice of educational institution. Since there were no previous data on which to model the questions, the authors used a large number of questions in an attempt to capture as many factors as possible. Additionally, five open-ended questions were added that sought to capture influential factors the researchers might have overlooked.

Prior to distribution, the survey was reviewed by a focus group consisting of a broad spectrum of aviation industry professionals. The group consisted of representatives from engineering, corporate aviation, aircraft maintenance, the Federal Aviation Administration (FAA), and a major avionics manufacturer.

The purpose of the survey and the proposed methodology were discussed with the group. Comprehensive reviews of the major influences in the choice of a career in aviation along with those for choosing an educational institution were performed. Each of the survey questions was reviewed for relevance and understanding. Questions were changed or added with group concurrence, with a final review by the entire group.

The department chair allowed the researchers to administer the survey at the beginning of 4 different classes, each class being a different class year (freshman, sophomore, junior and senior). Because the researchers administered the survey, the researchers were able to insure that the survey was administered consistently across all four classes. This was essentially a convenience sample that allowed the authors to obtain 62 surveys from a population of about 100 students. This proved to be a fast and reliable way to collect data. Students were given the option of not completing the survey if they did not want to participate. Students completed the surveys anonymously and handed them to the researcher when completed. The survey took about 15-20 minutes to complete on average. The researchers then entered the demographic and Likert data into SPSS version 15 for analysis. The open-ended questions were categorized using a word cloud program to identify common themes in the responses.

\section{DATA ANALYSIS}

\section{Demographics}

A review of the demographics showed that the aviation science student body was $92 \%$ male $(n=57)$, $92 \%$ white $(n=57)$, and $98 \%$ U.S. citizens $(n=61)$. The lack of international students was attributed to the increased security requirements imposed by the Transportation Security Administration (Transportation Security Administration, 2010) for foreign nationals to receive flight instruction in the United States. The sample size of each class was freshmen $n=13$, sophomores $n=20$, juniors $n=14$ and seniors $n=13$. Two students did not report their class standing. Due to the lack of racial, gender, and nationality diversity, no analyses were performed using those groups.

\section{Overall Results}

Initial analysis using SPSS version 15 included a mean ranking of the Likert scale questions for which the individual scores for each question from each respondent were totaled, and then divided by the 
number of responses. The questions were then ranked in descending order; with the highest average score answer being first, and the lowest average score being last. The responses were divided into two groups, answers for the Parks questions which were prefixed with a "P", and the aviation questions prefixed with an "A" (Appendix A). Table 2 shows the results of the Parks questions, while Table 3 shows the results of the aviation questions.

Table 2. Parks College Factors Results

\begin{tabular}{|l|c|c|c|c|c|}
\hline \multicolumn{1}{|c|}{ Parks College Factors } & & & & & \\
\hline & $\mathrm{N}$ & Min. & Max. & Mean & Std. Deviation \\
\hline Aviation reputation & 62 & 4 & 7 & 5.95 & 0.95 \\
\hline Academic reputation & 62 & 2 & 7 & 5.61 & 0.98 \\
\hline Obtaining job at graduation & 62 & 2 & 7 & 5.32 & 1.33 \\
\hline Quality of curriculum & 62 & 1 & 7 & 5.21 & 1.20 \\
\hline Campus visit & 62 & 1 & 7 & 5.15 & 1.30 \\
\hline Graduation rate & 62 & 2 & 7 & 5.13 & 1.27 \\
\hline Quality of faculty & 61 & 1 & 7 & 5.11 & 1.28 \\
\hline Employee value & 62 & 2 & 7 & 5.06 & 1.41 \\
\hline Classroom facilities & 62 & 1 & 7 & 4.98 & 1.09 \\
\hline Education accreditation & 62 & 1 & 7 & 4.95 & 1.29 \\
\hline University location & 62 & 1 & 7 & 4.92 & 1.60 \\
\hline Class size & 62 & 1 & 7 & 4.89 & 1.16 \\
\hline Information on Web & 62 & 2 & 7 & 4.84 & 1.23 \\
\hline Aircraft maintenance & 62 & 1 & 7 & 4.77 & 1.60 \\
\hline Scholarship availability & 61 & 1 & 7 & 4.62 & 1.85 \\
\hline Campus life & 62 & 1 & 7 & 4.60 & 1.31 \\
\hline Friend/relative recommendation & 62 & 1 & 7 & 4.53 & 1.55 \\
\hline Athletic facilities & 62 & 1 & 7 & 4.44 & 1.37 \\
\hline Safety record & 62 & 1 & 7 & 4.40 & 1.46 \\
\hline Parents wanted & 62 & 1 & 7 & 4.34 & 1.44 \\
\hline Job placement & 62 & 1 & 7 & 4.34 & 1.57 \\
\hline Entrance requirements & 62 & 1 & 7 & 4.31 & 1.25 \\
\hline Proximity to airport & 62 & 1 & 7 & 4.31 & 1.64 \\
\hline Computer facilities & 62 & 1 & 7 & 4.18 & 1.39 \\
\hline Financial aid & 62 & 1 & 7 & 4.15 & 2.01 \\
\hline Jesuit university & 62 & 1 & 7 & 3.95 & 1.74 \\
\hline Campus proximity to home & 62 & 1 & 7 & 3.92 & 2.14 \\
\hline Aircraft fleet & 62 & 1 & 7 & 3.90 & 1.42 \\
\hline Flight Simulators & 62 & 1 & 7 & 3.90 & 1.43 \\
\hline Campus security & 62 & 1 & 7 & 3.84 & 1.53 \\
\hline Student services & 61 & 1 & 7 & 3.69 & 1.42 \\
\hline Flight team & 62 & 1 & 7 & 3.61 & 1.49 \\
\hline HS guidance counselor & 62 & 1 & 7 & 3.37 & 1.85 \\
\hline Living costs & 62 & 1 & 7 & 2.74 & 1.41 \\
\hline Information on newspaper & 62 & 1 & 5 & 2.55 & 1.28 \\
\hline Information on radio & & 5 & 2.53 & 1.28 \\
\hline Tuition costs & & & & 1.39 \\
\hline Valid N (listwise) & & & \\
\hline
\end{tabular}


Table 3. Aviation Career Factor Results

\begin{tabular}{|l|c|c|c|c|c|}
\hline \multicolumn{1}{|c|}{ Aviation Career factors } & & & & & \\
\hline Wanted to be a professional pilot & $\mathrm{N}$ & Minimum & Maximum & Mean & Std. Deviation \\
\hline Wanted to be in aviation & 61 & 1 & 7 & 6.41 & 0.96 \\
\hline Job satisfaction & 61 & 2 & 7 & 6.13 & 1.44 \\
\hline Work with technology & 61 & 3 & 7 & 5.72 & 0.97 \\
\hline Opportunity for career advancement & 61 & 2 & 7 & 5.51 & 1.07 \\
\hline Prestige & 61 & 2 & 7 & 5.49 & 1.13 \\
\hline Travel opportunities & 61 & 1 & 7 & 5.44 & 1.43 \\
\hline Challenging career & 61 & 3 & 7 & 5.41 & 0.97 \\
\hline Salary considerations & 60 & 1 & 7 & 4.92 & 1.50 \\
\hline Employment opportunities & 61 & 1 & 7 & 4.72 & 1.39 \\
\hline Attended airshow(s) & 61 & 1 & 7 & 3.97 & 1.70 \\
\hline Working hours & 61 & 1 & 7 & 3.72 & 1.69 \\
\hline Industry job forecast & 61 & 1 & 7 & 3.56 & 1.58 \\
\hline Parent/Relative/Friend in aviation & 61 & 1 & 7 & 3.54 & 2.16 \\
\hline Job stability & 61 & 1 & 7 & 3.28 & 1.56 \\
\hline Easy entry career & 61 & 1 & 7 & 3.20 & 1.38 \\
\hline Job security & 61 & 1 & 6 & 3.00 & 1.45 \\
\hline SLU alumni influence & 61 & 1 & 7 & 2.97 & 1.60 \\
\hline Physical demands & 61 & 1 & 6 & 2.72 & 1.24 \\
\hline Easy major & 61 & 1 & 6 & 2.66 & 1.47 \\
\hline HS counselor influence & 61 & 1 & 6 & 2.39 & 1.32 \\
\hline Valid N (listwise) & 60 & & & & \\
\hline
\end{tabular}

Analysis of the data showed minor omissions in some of the question responses, but there was an insufficient number and no pattern of missing data to affect the analysis. There were no outliers.

\section{Parks College Analysis}

The analysis of factors affecting enrollment at Parks showed the top two factors were aviation reputation $(\mathrm{M}=5.95)$ and academic reputation $(\mathrm{M}=5.61)$. Observing the minimum-maximum scores showed that no one rated aviation reputation lower than a "4". Although these results replicated the top two factors in Clark's survey (Table 1), our survey used the average of all rankings within the factor, while Clark's study ranked the answers by only those answers in the "very influential" column, disregarding the results in the other columns. Clark chose to only report the top 10 factors in the "very influential" column. Because this was an exploratory survey, it was felt additional information could be obtained by reporting all factors.

Parks College does place an emphasis on campus visits by the parents and prospective student, and the survey results showed that "campus visit" is very influential $(\mathrm{M}=5.15)$, ranked as the $5^{\text {th }}$ most influential factor out of 37 factors, confirming that this is apparently an effective recruitment tool. Parks College also works with high school counselors and invites them to campus for a tour of the facilities and faculty discussions. The college covers the entire cost of these visits. The low score in both the Parks $(\mathrm{M}=3.37)$ and aviation ( $\mathrm{M}=2.39)$ survey was surprising and disappointing, pointing to the need to reassess this investment of resources. 
Incorporation of bar charts yielded some surprising results. A chart of the responses for "computer facilities" $(M=4.18)$ showed most of the responses as a "4," or "neutral" (Table 4). Conversation with the department chair revealed that approximately $98 \%$ of the students come to the university with their own computers, with most of these computers being newer and more powerful than those offered in the college's computer labs. It is felt that the respondents might have been confused and answered with a "neutral" response as opposed to a "highly disagree" response. This may also indicate that the question was irrelevant to the students. These results may also indicate the need to reword future surveys using the term "influential" as Clark did (Table 1) in the Likert scale as opposed to the words "agree" or "disagree". Several other factors that ranked near an average score of "4" had similar results, so the phenomena were not unique to this one factor.

Table 4. Computer Facilities Responses

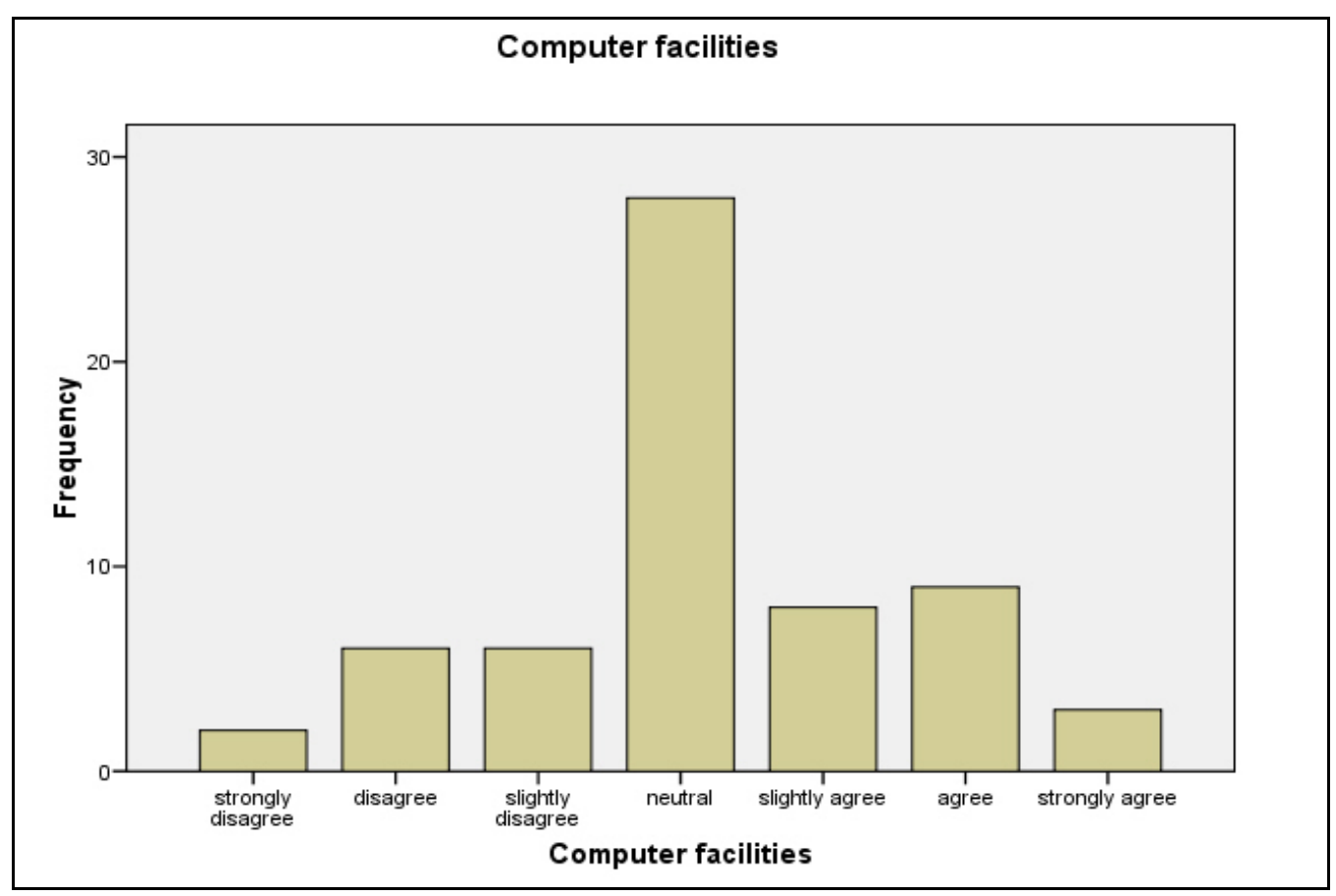

Parks had recently completed a media campaign within the St. Louis metropolitan area, so respondents were asked about the effectiveness of various forms of media. Table 2 shows that newspaper and radio advertising were apparently not effective in influencing enrollment at Parks College.

\section{Aviation Career Analysis}

The top two responses for the aviation career part of the survey were "wanted to be a professional pilot" ( $M=6.41)$ and wanted to be in aviation $(M=6.13)$. Many of the responses to the open-ended questions revealed the respondent had wanted to be a pilot and/or in aviation from an early age. These responses may warrant additional research to determine what factors influence students less than 18 years of age to become interested in aviation, and at what age that occurs. Surprisingly, factors that seemingly might have occurred at an earlier age to spark interest in aviation, including influence from a parent/friend/relative $(M=3.54)$, Saint Louis University alumni $(M=2.97)$ or high school counselor $(\mathrm{M}=2.39)$, scored relatively low versus some of the other factors. 


\section{Themes From Open-ended Questions}

As mentioned earlier, there were five open-ended questions at the end of the survey. Three of these questions were intended to provide an opportunity for students to comment further on factors that influenced their choice of career and institution. The fourth was a general question that gave students the chance to comment on anything about the program. This question revealed some likes and dislikes the students had concerning the program.

The responses from these questions were reviewed with common themes identified. The comments were then coded and grouped into these themes. To visually depict the higher occurrences of these themes, the Wordle application (Feinberg, 2010) was used to create Word Clouds. These clouds create a visual scale of the common themes. Themes which occurred most often are depicted with larger, bolder type. Only themes which had three or more responses were captured in the word clouds.

Four of the questions with a summary of the findings and the corresponding Word Cloud are found below.

\section{Question \#1: Do you have any other comments regarding the Aviation Science program at Saint Louis University?}

This question resulted in two predominate recurring themes (Figure 1). By far the most predominate was that students dislike the training aircraft because they are not certified to FAA regulations to be flown in actual instrument meteorlogical conditions (IMC). The other predominant theme was the high cost of flight training.

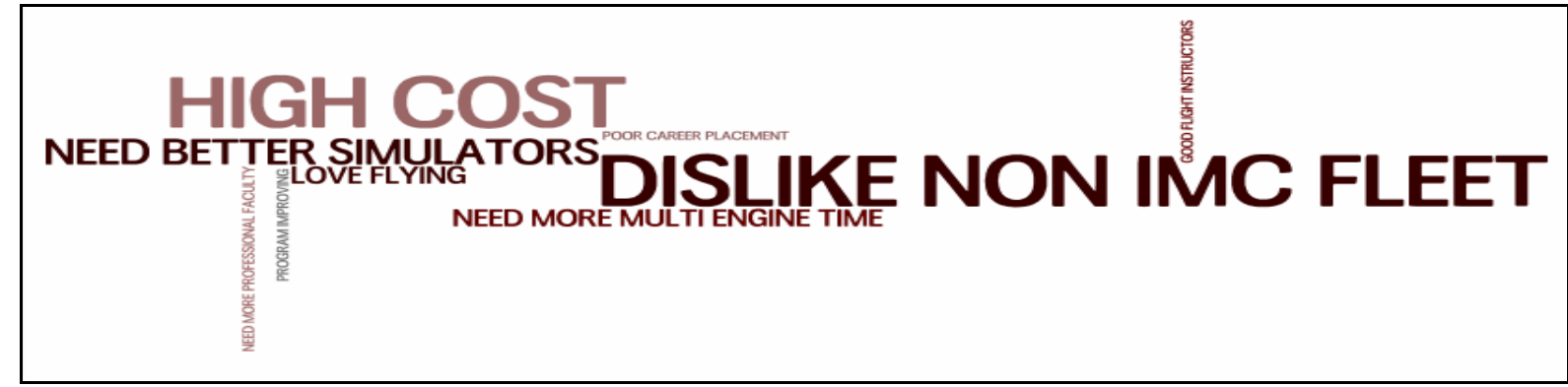

Figure 1. Question 1 recurring themes

\section{Question \#2: Are there any other factors that influenced your decision in selecting Saint Louis University?}

The top themes from this question were the location of the university, reputation of Parks and SLU, and scholarship award (Figure 2). The influence of Parks College Air Force ROTC and Rifle team are themes that could be explored further in a subsequent survey. 


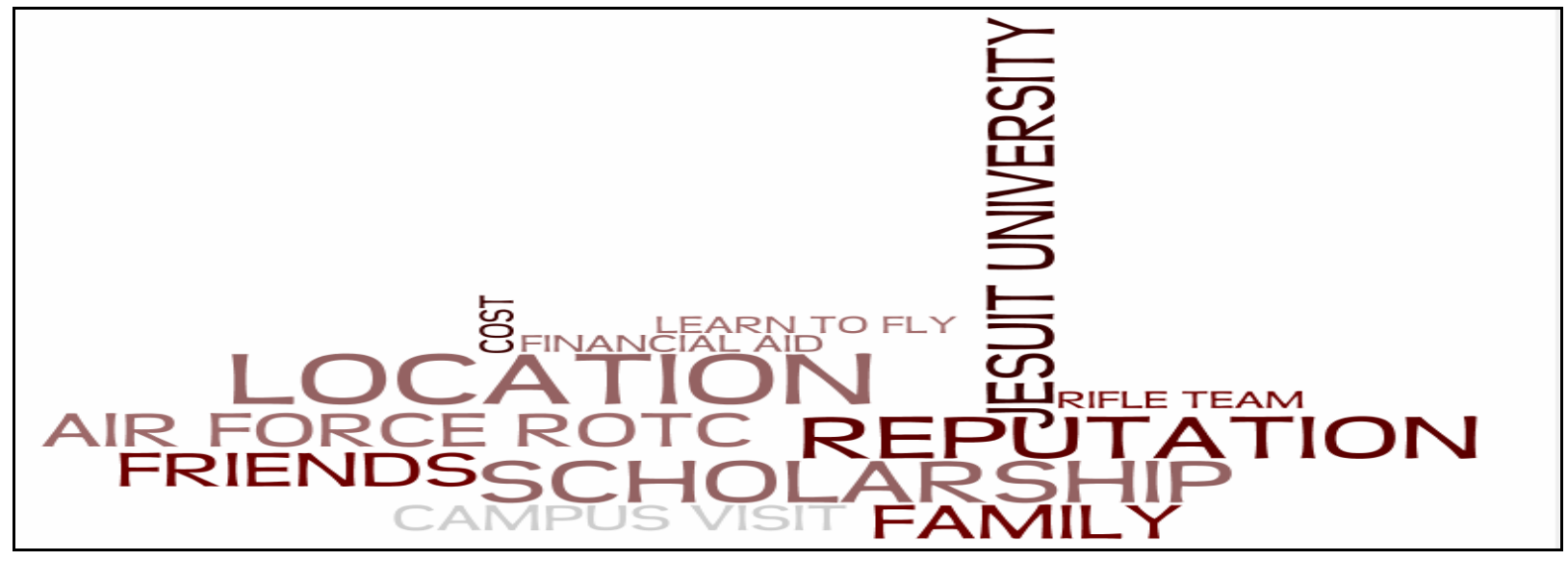

Figure 2. Question 2 recurring themes

Question \#3: What other institutions did you consider before selecting Saint Louis University?

Embry Riddle University ( $\mathrm{n}=21)$ and Purdue University $(\mathrm{n}=13)$ were by far the most cited institutions that students considered attending (Figure 3).

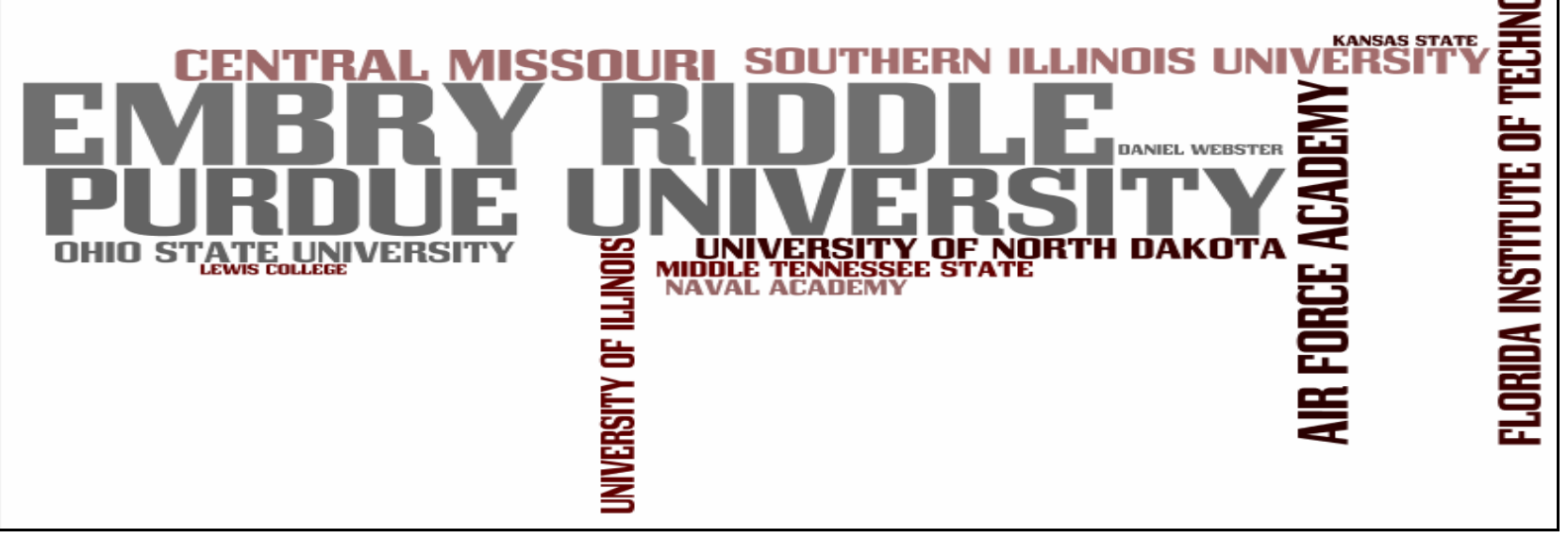

Figure 3. Question 3 recurring themes

Question \#4: What other factors influenced your decision to pursue a career in aviation?

Love of flying was the dominant factor in why students chose a career in aviation (Figure 4). It was also interesting to note that some of the respondents indicated their love of flying started at an early age, which implies that recruitment for university flight programs should start prior to high school. 


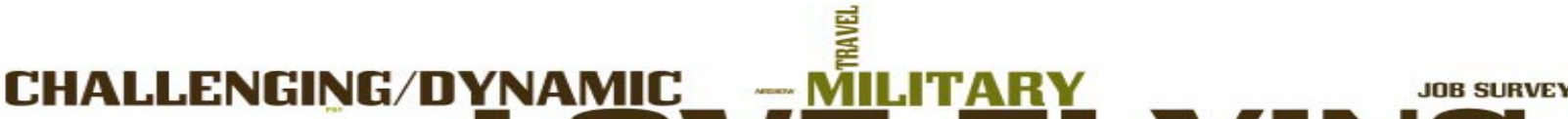 LOVE FLYING}

Figure 4. Question 4 recurring themes

\section{DISCUSSION}

This survey was a successful initial assessment of the factors that influenced students in choosing aviation as a career and Parks College for an aviation education. The survey was exploratory and uncovered additional areas of consideration that should be included in subsequent surveys. This includes further inquiry into career placement, flight training, aircraft fleet, and facilities. Overall, the survey determined current students are pleased with their choice to pursue a career in aviation as well as their selection of Parks College. The academic reputation of Saint Louis University, the reputation of Parks College in the aviation community, and the student's love of aviation were overwhelming selection factors.

A final analysis was presented to the aviation science faculty. The Aviation Science department has expressed an interest in making this an annual assessment to further improve the department and ultimately provide the best possible education and experience for students. Repeated measures will allow analysis of process improvements and the effect of any interventions over time. This information can be used to add or drop factors in future surveys, and to determine if factors become more or less important over time. The results of this survey also will help the school more effectively focus its limited marketing budget.

Improvements to be included in subsequent surveys include changing the Likert scale questions from an "agree/disagree" format to varying degrees of "influential" to avoid non-influential factors possibly being coded as "neutral". Future surveys will create new Likert scale questions reflecting the results of the open-ended questions, and Likert scale responses deemed as not being influential will be dropped. The results of this and future surveys provide valuable information for decisions involving strategic planning, financial considerations, and ultimately a valuable tool in the continuous improvement process at Parks College. 


\section{REFERENCES}

Astin, A.W., Korn, W.S., \& Berz, E.R. (1991). The American freshman: national norms for fall 1990. Los Angeles: Higher Education Research Institute, UCLA.

Clark, J. M. (2004). A descriptive research survey study that examined factors influencing selection of four-year post-secondary commercial aviation programs. Ph.D. dissertation, The University of Mississippi, United States -- Mississippi. Retrieved January 13, 2010, from Dissertations \& Theses: Full Text. (Publication No. AAT 3136219).

Feinberg, J. (2010). Wordle. Retrieved May 3, 2010 from http://www.wordle.net/.

Transportation Security Administration (2010). Alien flight student program. Retrieved May 1, 2010 from: https://www.flightschoolcandidates.gov/afsp2/?acct_type $=$ c\&section=WN

Wendt, K.R. (1991). Typical incoming Parks student: Spring 1991 college student inventory results $(N=97)$. St. Louis, Missouri, Saint Louis University. 


\section{Appendix A \\ Survey instrument \\ Saint Louis University - Parks College Aviation Sciences Student Survey}

Please answer the following questions as accurately and honestly as possible. All responses will be kept strictly anonymous, so please do not put your name on the questionnaire. The results will only be reported in aggregate form.

Purpose of this survey: To research those factors that influence an undergraduate student to choose a career in aviation, and enroll in the Aviation Science program at Parks College of Engineering Aviation and Technology.

\section{Investigators:}

Richard Steckel: $\quad$ Principal Investigator, Doctoral Student and Research Assistant, Parks College of Engineering, Aviation and Technology

Damon Lercel: $\quad$ Investigator, Doctoral Student, Parks College of Engineering, Aviation and Technology

\section{General Information}

Questions 1 - 9. Circle the appropriate response or fill in the blank.

1-Gender $\quad M \quad F$

2-Age

3-Major Aviation Management

Flight Science

Undeclared

Other

$\underline{4-\text { U.S. or international student }}$

U.S. International

5-Year in college $\quad$ Freshman Sophomore Junior Senior

6-Ethnicity Asian/Pacific Islands Latino African American White Other

7-Parent(s) attended SLU? $\quad$ Yes $\quad$ No

8 - Parent(s) employed by SLU? $\quad$ Yes $\quad$ No 


\begin{tabular}{|c|c|c|c|c|c|c|c|}
\hline $\begin{array}{l}\text { For the following statements, please circle your level of } \\
\text { agreement or disagreement from } 1 \text { (Strongly Disagree) to } \\
7 \text { (Strongly Agree). } \\
\text { In general, I selected Parks College Aviation Science } \\
\text { program for the following reasons: }\end{array}$ & 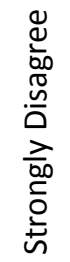 & 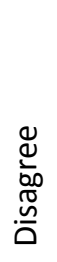 & 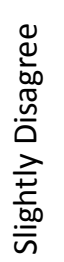 & $\begin{array}{l}\bar{\pi} \\
\frac{\pi}{3} \\
\frac{0}{2}\end{array}$ & 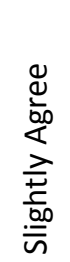 & $\frac{d}{\frac{d}{\alpha 0}}$ & 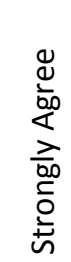 \\
\hline P1. Academic reputation & 1 & 2 & 3 & 4 & 5 & 6 & 7 \\
\hline P2. Parks College's reputation in Aviation & 1 & 2 & 3 & 4 & 5 & 6 & 7 \\
\hline P3. My high school guidance counselor recommended SLU & 1 & 2 & 3 & 4 & 5 & 6 & 7 \\
\hline P4. My parents wanted me to attend Saint Louis University & 1 & 2 & 3 & 4 & 5 & 6 & 7 \\
\hline P5. Availability of financial aid & 1 & 2 & 3 & 4 & 5 & 6 & 7 \\
\hline P6. $\quad$ Aircraft fleet used for flight training & 1 & 2 & 3 & 4 & 5 & 6 & 7 \\
\hline P7. Safety record of the flight training program & 1 & 2 & 3 & 4 & 5 & 6 & 7 \\
\hline P8. Campus security & 1 & 2 & 3 & 4 & 5 & 6 & 7 \\
\hline P9. University location & 1 & 2 & 3 & 4 & 5 & 6 & 7 \\
\hline P10. Reasonable tuition costs & 1 & 2 & 3 & 4 & 5 & 6 & 7 \\
\hline P11. Level of student services (housing, food, health) & 1 & 2 & 3 & 4 & 5 & 6 & 7 \\
\hline P12. Class size & 1 & 2 & 3 & 4 & 5 & 6 & 7 \\
\hline P13. Campus visit & 1 & 2 & 3 & 4 & 5 & 6 & 7 \\
\hline P14. Information from university web site/advertising/literature & 1 & 2 & 3 & 4 & 5 & 6 & 7 \\
\hline P15. Information from a SLU radio advertisement & 1 & 2 & 3 & 4 & 5 & 6 & 7 \\
\hline P16. Information from a SLU newspaper advertisement & 1 & 2 & 3 & 4 & 5 & 6 & 7 \\
\hline P17. Recommendation from a friend or relative & 1 & 2 & 3 & 4 & 5 & 6 & 7 \\
\hline P18. Competitive flight team & 1 & 2 & 3 & 4 & 5 & 6 & 7 \\
\hline P19. Campus life/activities & 1 & 2 & 3 & 4 & 5 & 6 & 7 \\
\hline P20. Educational accreditations & 1 & 2 & 3 & 4 & 5 & 6 & 7 \\
\hline P21. Career placement program & 1 & 2 & 3 & 4 & 5 & 6 & 7 \\
\hline P22. Employers value of a SLU degree & 1 & 2 & 3 & 4 & 5 & 6 & 7 \\
\hline
\end{tabular}




\begin{tabular}{|c|c|c|c|c|c|c|c|}
\hline $\begin{array}{l}\text { For the following statements, please circle your level of } \\
\text { agreement or disagreement from } 1 \text { (Strongly Disagree) to } \\
7 \text { (Strongly Agree). } \\
\text { In general, I selected Parks College Aviation Science } \\
\text { program over other university programs for the following } \\
\text { reasons: }\end{array}$ & 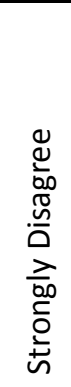 & 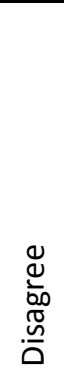 & 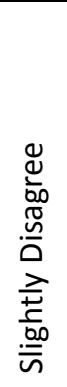 & 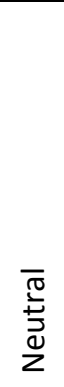 & 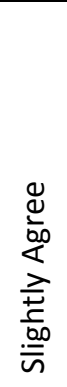 & $\underset{\frac{1}{\infty}}{\stackrel{00}{\alpha}}$ & 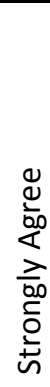 \\
\hline P23. Ability to obtain a desirable job upon graduation & 1 & 2 & 3 & 4 & 5 & 6 & 7 \\
\hline P24. Jesuit university & 1 & 2 & 3 & 4 & 5 & 6 & 7 \\
\hline P25. Proximity of the airport to the campus & 1 & 2 & 3 & 4 & 5 & 6 & 7 \\
\hline P26. Flight simulators & 1 & 2 & 3 & 4 & 5 & 6 & 7 \\
\hline P27. Proximity of the campus to my home & 1 & 2 & 3 & 4 & 5 & 6 & 7 \\
\hline P28. Quality of the faculty & 1 & 2 & 3 & 4 & 5 & 6 & 7 \\
\hline P29. Classroom facilities & 1 & 2 & 3 & 4 & 5 & 6 & 7 \\
\hline P30. Onsite aircraft maintenance & 1 & 2 & 3 & 4 & 5 & 6 & 7 \\
\hline P31. Availability of scholarships & 1 & 2 & 3 & 4 & 5 & 6 & 7 \\
\hline P32. Entrance requirements for the college & 1 & 2 & 3 & 4 & 5 & 6 & 7 \\
\hline P33. Quality of the curriculum & 1 & 2 & 3 & 4 & 5 & 6 & 7 \\
\hline P34. Four year graduation rate & 1 & 2 & 3 & 4 & 5 & 6 & 7 \\
\hline P35. Computer facilities & 1 & 2 & 3 & 4 & 5 & 6 & 7 \\
\hline P36. Athletic facilities & 1 & 2 & 3 & 4 & 5 & 6 & 7 \\
\hline P37. Living costs (including housing) & 1 & 2 & 3 & 4 & 5 & 6 & 7 \\
\hline P41. I am satisfied with the Aviation Science Program at Parks. & 1 & 2 & 3 & 4 & 5 & 6 & 7 \\
\hline P42. I made the right choice in attending Parks. & 1 & 2 & 3 & 4 & 5 & 6 & 7 \\
\hline P43. If I had to choose again, I would choose to attend Parks. & 1 & 2 & 3 & 4 & 5 & 6 & 7 \\
\hline
\end{tabular}




\begin{tabular}{|c|c|c|c|c|c|c|c|}
\hline $\begin{array}{l}\text { For the following statements, please circle your level of } \\
\text { agreement or disagreement from } 1 \text { (Strongly Disagree) to } \\
7 \text { (Strongly Agree). } \\
\text { In general, I chose to pursue a career in aviation for the } \\
\text { following reasons: }\end{array}$ & 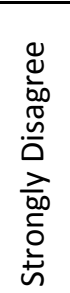 & 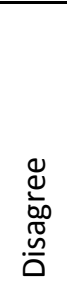 & 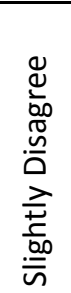 & 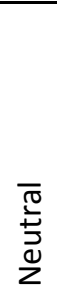 & 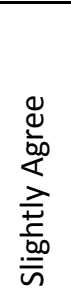 & 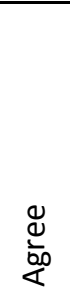 & 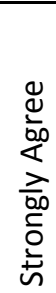 \\
\hline A1. Salary considerations & 1 & 2 & 3 & 4 & 5 & 6 & 7 \\
\hline A2. Always wanted to be in aviation & 1 & 2 & 3 & 4 & 5 & 6 & 7 \\
\hline A3. Thought it would be an easier college major & 1 & 2 & 3 & 4 & 5 & 6 & 7 \\
\hline A4. Wanted to be a professional pilot & 1 & 2 & 3 & 4 & 5 & 6 & 7 \\
\hline A5. Parents/relatives/friends are involved in aviation & 1 & 2 & 3 & 4 & 5 & 6 & 7 \\
\hline A6. Travel opportunities & 1 & 2 & 3 & 4 & 5 & 6 & 7 \\
\hline A7. Employment Opportunities & 1 & 2 & 3 & 4 & 5 & 6 & 7 \\
\hline A8. Low physical demands & 1 & 2 & 3 & 4 & 5 & 6 & 7 \\
\hline A9. Attending an air show & 1 & 2 & 3 & 4 & 5 & 6 & 7 \\
\hline A10. Job Security & 1 & 2 & 3 & 4 & 5 & 6 & 7 \\
\hline A11. Challenging career & 1 & 2 & 3 & 4 & 5 & 6 & 7 \\
\hline A12. Job Satisfaction & 1 & 2 & 3 & 4 & 5 & 6 & 7 \\
\hline A13. Industry job forecast & 1 & 2 & 3 & 4 & 5 & 6 & 7 \\
\hline A14. Prestige & 1 & 2 & 3 & 4 & 5 & 6 & 7 \\
\hline A15. Working with sophisticated technology & 1 & 2 & 3 & 4 & 5 & 6 & 7 \\
\hline A16. Opportunities for career advancement & 1 & 2 & 3 & 4 & 5 & 6 & 7 \\
\hline A17. Reasonable work hours & 1 & 2 & 3 & 4 & 5 & 6 & 7 \\
\hline A18. Job Stability & 1 & 2 & 3 & 4 & 5 & 6 & 7 \\
\hline A19. Ease of entry into career field & 1 & 2 & 3 & 4 & 5 & 6 & 7 \\
\hline A20. Influence from SLU alumni & 1 & 2 & 3 & 4 & 5 & 6 & 7 \\
\hline A21. Influence from high school counselor & 1 & 2 & 3 & 4 & 5 & 6 & 7 \\
\hline A23. I am satisfied with my decision to pursue a career in & 1 & 2 & 3 & 4 & 5 & 6 & 7 \\
\hline A24. I made the right choice selecting an aviation career. & 1 & 2 & 3 & 4 & 5 & 6 & 7 \\
\hline $\begin{array}{l}\text { A25. If I had to choose again, I would again select a career in } \\
\text { aviation. }\end{array}$ & 1 & 2 & 3 & 4 & 5 & 6 & 7 \\
\hline
\end{tabular}


A26. Are there any other factors that influenced your decision in selecting Saint Louis University?

A27. Which other institutions did you consider before selecting SLU?

A28. What other factors influenced your decision to pursue a career in aviation?

A29. Do you have any other comments regarding the Aviation Science Program at Saint Louis University?

A30. In your opinion, with a limited budget, what would be the most effective use of marketing resources to attract prospective aviation science students to attend Parks College of Engineering, Aviation and Technology? 